\title{
Doublecortin-Positive Cells in the Adult Primate Cerebral Cortex and Possible Role in Brain Plasticity and Development
}

\author{
Jocelyne Bloch, ${ }^{1}$ Mélanie Kaeser, ${ }^{1,2}$ Yalda Sadeghi, ${ }^{1}$ Eric M. Rouiller, ${ }^{2}$ D. Eugene Redmond, JR, ${ }^{3}$ \\ and Jean-François Brunet ${ }^{1 *}$ \\ ${ }^{1}$ Neurosurgery Research Group, CHUV-UNIL, CH-1011 Lausanne, Switzerland \\ ${ }^{2}$ Unit of Physiology, Department of Medicine, University of Fribourg, CH-1700 Fribourg, Switzerland \\ ${ }^{3}$ Department of Psychiatry and Neurosurgery, Yale University School of Medicine, New Haven, Connecticut 06520
}

\begin{abstract}
We have demonstrated that cortical cell autografts might be a useful therapy in two monkey models of neurological disease: motor cortex lesion and Parkinson's disease. However, the origin of the useful transplanted cells obtained from cortical biopsies is not clear. In this report we describe the expression of doublecortin (DCX) in these cells based on reverse-transcription polymerase chain reaction (RT-PCR) and immunodetection in the adult primate cortex and cell cultures. The results showed that DCX-positive cells were present in the whole primate cerebral cortex and
\end{abstract}

also expressed glial and/or neuronal markers such as glial fibrillary protein (GFAP) or neuronal nuclei (NeuN). We also demonstrated that only DCX/GFAP positive cells were able to proliferate and originate progenitor cells in vitro. We hypothesize that these DCX-positive cells in vivo have a role in cortical plasticity and brain reaction to injury. Moreover, in vitro these DCX-positive cells have the potential to reacquire progenitor characteristics that confirm their potential for brain repair. J. Comp. Neurol. 519:775-789, 2011.

INDEXING TERMS: DCX; adult primate cortex; Macaque monkey; green monkey; human, adult brain cell

Doublecortin (DCX) was first described in X-linked lissencephaly and "double cortex" allelic human disorders mapping to Xq22.3-Xq23. DCX is associated with arrest of migrating cerebral cortical neurons (des Portes et al., 1998; Gleeson et al., 1998). DCX was identified as the microtubule-associated protein expressed by migrating neuroblasts during a limited phase of their development in both developing and adult mammals (Matsuo et al., 1998; Francis et al., 1999; Gleeson et al., 1999; Brown et al., 2003). DCX plays a crucial role for microtubule stabilization (Gleeson et al., 1999) and nuclear translocation during neuronal migration (Koizumi et al., 2006) as well as in growth cone dynamics (Burgess and Reiner, 2000). In the rodent nervous system, DCX expression is induced in fast-dividing neuronal precursors, persists for $\approx 30$ days, and is terminated thereafter as a consequence of neuronal maturation (Brown et al., 2003). During the important step of cell migration in neuronal development, DCX participates in the regulation of microtubule dynamics and stability during neuronal morphogenesis (Horesh et al., 1999). In the adult brain it is now commonly accepted that DCX is expressed in areas of neurogenesis, indeed in the subventricular zone as well as the hippocampus. Outside these neurogenic niches, DCX was previously thought to be almost absent (Omori et al., 1998; Brown et al., 2003). However, more recently the presence of DCX-positive cells was described in the cerebral cortex of guinea pig, cat, and primate, suggesting

Additional supporting information may be found in the online version of this article.

Grant sponsor: FNRS; Grant numbers: 3200-059139.99 (to J.G.V. and J.F.B.), 3100AO-103924 (to J.B. and J.F.B.), 31-61857.00 and 310000110005 (to E.M.R.); Grant sponsors: Axion Research Foundation, St. Kitts Biomedical Research Foundation, LEENAARDS Foundation, Novartis Foundation, National Centre of Competence in Research (NCCR) on "Neural plasticity and repair", Christopher Reeves Foundation (Springfield NJ), Lausanne University Hospital Neurosurgery Department.

${ }^{*}$ CORRESPONDENCE TO: Jean-François Brunet, Neurosurgery Research Group, CHUV-UNIL, EPCR22 02/219, Chemin des Croisettes 22, CH-1066 Epalinges, Switzerland. E-mail: Jean-Francois.Brunet@chuv.ch 
that these cells might be developing interneurons (Xiong et al., 2008; Cai et al., 2009). Based on recent animal studies, it is now conceivable that some precursor cells in the human cortex proceed to the neuronal lineage (Jessberger et al., 2005). As a consequence, cells expressing the marker of immature neurons (DCX) might be detectable in adult human neocortex and play a role, not as a neurogenic marker, but in glia-to-neuron signaling mediating synaptic or metabolic plasticity (Verwer et al., 2007).

In human brain, some have argued in favor of the crucial role of DCX in neuronal migration based on its expression in cytomegalic neurons and balloon cells in the cortical lesions of tuberous sclerosis and focal cortical dysplasia. These lesions show a disturbance in laminar architecture and cell differentiation (Mizuguchi et al., 2002). Since its pattern of expression is observed in different neuronal developmental contexts, DCX has been considered a possible internal indicator for neurogenesis (Brown et al., 2003). Evidence from animal models indicates that during injury, such as ischemic events or seizure induction, the neurogenic response is associated with the transient increased expression of DCX in adult rodent brain (Arvidsson et al., 2002; Brown et al., 2003; Couillard-Despres et al., 2005). Observations in rodents during increased physical activities, environmentally enriched conditions, or aging demonstrated that DCX was closely correlated with the neurogenesis in two specific brain structures: the subventricular zone (SVZ) and the subgranular zone of the dentate gyrus (DG) (Brown et al., 2003; Couillard-Despres et al., 2005; Rao et al., 2005). Moreover, DCX continued to be expressed in many cells of the adult rat telencephalon apart from the rostral migratory stream, especially in the corpus callosum and the piriform cortex, suggesting that continuous migration of neuronal precursors may still occur in these areas during adulthood (Nacher et al., 2001). More recently, the presence of newly generated neurons has been described in the adult rat paleocortex layer II (Pekcec et al., 2006; Shapiro et al., 2007a,b). These cells appear to be generated during embryonic development mainly at embryonic day (E) 15.5 and persisted in the paleocortex layer II over time (Gomez-Climent et al., 2008). DCX-positive cells have also been described in the cortex layer II of the adult guinea pig (Xiong et al., 2008). In nonhuman primate piriform cortex and in the human olfactory bulb, newly generated neurons are also observed by immunostaining with other neurogenesis markers such as polysialylated neural cell adhesion molecule (PSA-NCAM), beta-tubulinIII, collapsin response mediator protein-4, neuronal nuclear protein, and DCX (Bernier et al., 2002). The presence of newly generated neurons was also described in the primate striatum after a single injection of an adenovirus vector expressing brain-derived neurotrophic factor (BDNF) (Bedard et al., 2006). In human brain, a recent study based on autopsy and surgically resected tissue from 60 patients first reported the presence of DCX-positive cells in the neocortex, where a minority of them also expressed the astrocytic marker glial fibrillary protein (GFAP) (Verwer et al., 2007).

The aims of the present study were to delineate the DCX expression in primate neocortex, the distribution of DCX-positive cells in the cerebral cortex, and to show their potential link with the progenitor adult brain cells obtained in culture from neocortical biopsies (Arsenijevic et al., 2001; Brunet et al., 2002, 2003), a technique that we have developed over a decade. This technique represents a new source of cells for transplantation since these progenitors survive over time after reimplantation and differentiate into neurons (Brunet et al., 2005). The potential therapeutic impact is being evaluated for functional recovery and brain repair in nonhuman primate models of brain injury or neurodegenerative disease.

\section{MATERIALS AND METHODS}

This report is based on tissue from human and nonhuman primate brains. The pieces of cerebral cortex and brains were obtained from three adult cynomolgus monkeys (Macaca fascicularis). Biopsies and brains were also obtained from two adult African green monkeys (Chlorocebus sabaeus) from St. Kitts Biomedical Research Foundation (St. Kitts-Nevis). Pieces of six brain resections from human neurosurgery were obtained from trauma $(n=4)$ and epilepsy neurosurgeries $(n=2)$ in accordance with the local ethical committee of Lausanne University Hospital. The animal tissues were obtained in accordance with the Guide for Care and Use of Laboratory Animals (ISBN 0-309-05377-3; 1996) and approved by Swiss veterinary authorities, including the cantonal Survey Committee on Animal Experimentation and the Federal Veterinary Office (BVET, Bern, Switzerland). Tissues from St. Kitts monkeys were obtained with the approval of the St. Kitts's Institutional Animal Care and Use Committee (IACUC) and imported under an importation agreement (38925) under the Convention for Trade in Endangered Species (CITES), although the St. Kitts monkeys are not endangered.

\section{Antibody characterization}

The primary antibodies are described in detail in Table 1. The four anti-DCX antibodies were raised against a synthetic peptide (manufacturer's technical information), which corresponds to amino acids 385-402 of human DCX. The manufacturer's positive controls are mouse brain lysate (Abcam, Cambridge, MA), hDCX:293T and the human neuroblastoma SK-N-SH cell line lysates 
TABLE 1.

\begin{tabular}{|c|c|c|c|}
\hline Antigen & Immunogen/peptide & Species & Catalog Number and Source \\
\hline BrdU & $\begin{array}{l}\text { Bromodeoxyuridine conjugated } \\
\text { to bovine serum albumin }\end{array}$ & $\begin{array}{l}\text { Mouse monoclonal } \\
\text { igG1 clone Bu20a }\end{array}$ & M0744, Dako, Glostrup, Denmark \\
\hline DCX & YLPLSLDDSDSLGDSM & rabbit polyclonal IgG & ab 18723, Abcam, Cambridge, MA \\
\hline DCX & DLYLPLSLDDSDSLGDSM & goat polyclonal IgG & Sc-8066, Santa Cruz Biotechnology, California, USA \\
\hline DCX & YLPLSLDDSDSLGDSM & guinea pig polyclonal IgG & AB2253, Millipore, Billerica, Massachusetts, USA \\
\hline DCX & YLPLSLDDSDSLGDSM & guinea pig polyclonal IgG & AB5910, Millipore, Billerica, Massachusetts, USA \\
\hline GFAP & purified pig spinal cord GFAP & $\begin{array}{l}\text { Mouse monoclonal lgG1 } \\
\text { clone GA5 }\end{array}$ & G3893, Sigma-Aldrich, Buchs, Switzerland \\
\hline GFAP & Purified bovine GFAP & Chicken polyclonal IgY & AB5541, Millipore, Billerica, Massachusetts, USA \\
\hline GFAP & Purified cow spinal cord GFAP & rabbit polyclonal IgG & Z0334 DAKO, Glostrup, Denmark \\
\hline Nestin & $\begin{array}{l}150 \text { amino-acid nestin fragment } \\
\text { coupled to glutathione S-transferase } \\
\text { (Messam etal., 2000) }\end{array}$ & rabbit polyclonal IgG & AB5922, Millipore, Billerica, Massachusetts, USA \\
\hline NeuN & Purified cell nuclei from mouse brain & $\begin{array}{l}\text { Mouse monoclonal lgG } 1 \\
\text { clone A60 }\end{array}$ & MAB377, Millipore, Billerica, Massachusetts, USA \\
\hline vimentin & Purified porcine eye lens vimentin & $\begin{array}{l}\text { Mouse monoclonal IgG1 } \\
\text { clone V9 }\end{array}$ & M0725, Dako, Glostrup, Denmark \\
\hline
\end{tabular}

(Santa Cruz Biotechnology, Santa Cruz, CA) and rat brain lysate (Millipore, Bedford MA; Chemicon, Temecula, CA). For all four antibodies the peptides used were totally homologous with the monkey sequences based on the GenBank database (Macaca mulatta XM_001100519 and Pongo abelii XM_002831997). All four antibodies against DCX showed the same immunohistochemistry and were confirmed by western blots. As expected, all these antisera detected a 40-45-kDa band in human and monkey brain cell lysates (Figs. 4 and S1).

The three anti-GFAP antibodies detected a 50-55-kDa band in human and monkey brain cell lysates and stained cells with the classic morphology and distribution of fibrillary astrocytes (Benton et al., 2008; Komitova et al., 2009). The anti-Nestin antibody that was raised against a recombinant protein corresponding to amino acids 14641614 (Messam et al., 2000) detected a 200-220-kDa band in human and monkey brain cell lysates. According to the manufacturer's information, the anti-vimentin polyclonal antibodies do not work for western blot but stained cells with the classic morphology of glial progenitors (Ponti et al., 2006; Pecchi et al., 2007).

The specificity of the secondary conjugated antibodies was controlled by omitting the first antibody and crossreaction was also verified. In brief, during the first incubation only one primary antibody was present, for example, mouse anti-GFAP. The second incubation was done with the corresponding species secondary antibodies against mouse Ig, rabbit Ig, goat Ig, and guinea pig Ig conjugated with Alexa 488, Alexa 597, and Alexa 680, with a counterstaining of nuclei with DAPI. All secondary antibodies were controlled for crossreaction through incubation without primary antibody (Supplemental Data Fig. S2).

\section{Production of in vitro adult human and nonhuman primate brain cells}

The $1-\mathrm{cm}^{3}$ piece of resected cortex was washed three times in phosphate-buffered saline (PBS) supplemented with $33 \mathrm{mM}$ glucose, $60 \mathrm{mg} / \mathrm{L}$ penicillin, and $100 \mathrm{mg} / \mathrm{L}$ streptomycin. If delayed more than 2 hours before seeding cells in culture, the brain samples were kept in Hibernate A Medium (BrainBits, UK) at room temperature, as lower temperatures were disadvantageous for viability. Under a sterile environment, cortical tissue was washed another three times in sterile PBS-glucose with antibiotics and well orientated from the cortical surface to the white matter, sliced with a razor blade to obtain enriched fractions in the different gray matter (GM), and white matter (WM) layers as shown in Figure 1.

For each slice, primary cultures were generated by mincing and mechanically triturating the tissue with firepolished glass pipettes of decreasing diameters. Cells were plated at 250,000 cells $/ \mathrm{cm}^{2}$ in RPMI 1640 medium (Gibco, Gaithersburg, MD) supplemented with glucose $25 \mathrm{mM}$, glutamine $2 \mathrm{mM}, 10-20 \%$ preselected fetal bovine serum (pFBS), and an antibiotic/antimycotic cocktail (A7292 Sigma-Aldrich, Buchs, Switzerland) directly on a glass coverslip for immunocytochemistry or on plastic dishes at $37^{\circ} \mathrm{C}$ in a water-saturated atmosphere containing 6.5\% $\mathrm{CO}_{2} / 93.5 \%$ air.

For each fraction, primary cultures were generated by mincing and mechanically triturating the tissue with firepolished glass pipettes of decreasing diameters. Cells were plated at 250,000 cells $/ \mathrm{cm}^{2}$ in RPMI 1640 medium (Gibco) supplemented with glucose $25 \mathrm{mM}$, glutamine $2 \mathrm{mM}, 10-20 \%$ pFBS, and an antibiotic/antimycotic cocktail (A7292, Sigma-Aldrich) directly on a glass coverslip 


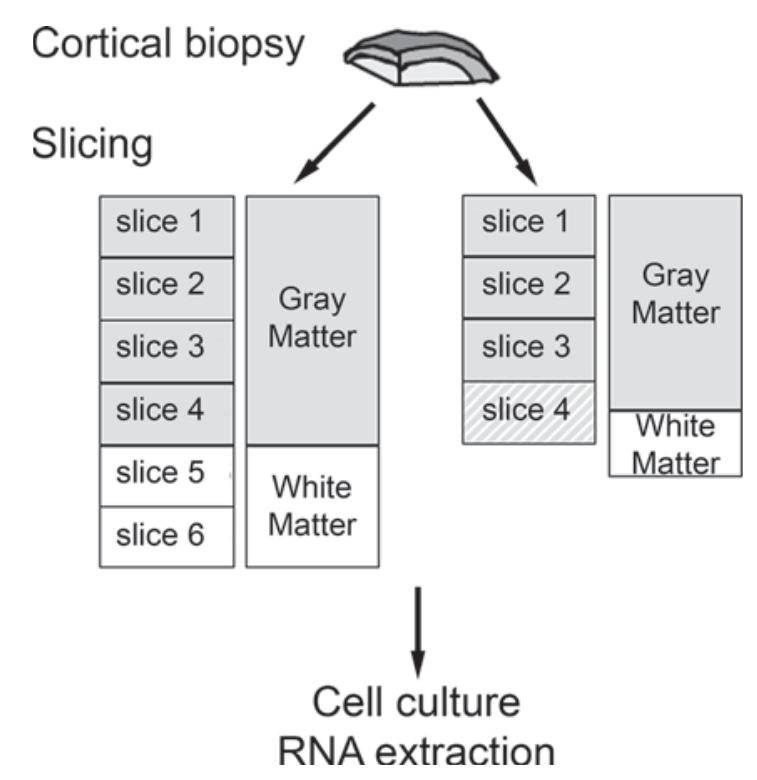

Figure 1. Outline of the cortical slicing method. As described in the text, the cortical biopsy was oriented from glia limitans to white matter. It was then sliced parallel to the cortical surface with a razor blade to obtain four or six layer-enriched fractions. Each fraction was then separately minced and dissociated to obtain cell cultures or to extract total RNA. In parallel, gray matter and white matter fractions were also minced and dissociated as described previously (Brunet et al., 2002).

for immunocytochemistry or on plastic dishes at $37^{\circ} \mathrm{C}$ in a water-saturated atmosphere containing $6.5 \% \quad \mathrm{CO}_{2} /$ 93.5\% air.

Observation of cultures with phase contrast microscopy or with light microscopy after fixation and staining with hematoxylin revealed the same morphological characteristics in human and nonhuman primary brain cell culture. Characterization was done by immunocytofluorescence for glial markers such as GFAP, vimentin, and neural stem cell/progenitor markers such as nestin and DCX.

\section{Immunohistochemistry}

Immunohistological staining was performed on 50- $\mu \mathrm{m}$ thick formalin-fixed cryosections or 4- $\mu \mathrm{m}$ thick formalinfixed paraffin-embedded sections. Immunohistological characterization was done for glial markers such as GFAP and vimentin, neuronal markers such as neuronal nuclei (NeuN), and neural stem cell/progenitor markers such as nestin and DCX.

The immunoreactions were revealed with biotinylated secondary antibodies followed by the immunoperoxidase Vectastain Elite system (PK-6100, Vector Laboratories, Burlingame, CA) and DAB substrate kit (SK-4100, Vector Laboratories) and counterstained with Mayer's hematoxylin solution (MHS32, Sigma-Aldrich). The DAB immuno- staining was observed under light microscope (BX40 Olympus) for DAB. The immunohistofluorescence was performed with fluorescent dye conjugated secondary antibodies. The macroscope images were obtained using the Odyssey system (LI-COR, Bad Homburg, Germany) that consists of scanning at $700 \mathrm{~nm}$ and $800 \mathrm{~nm}$ infrared fluorescent dyes with a resolution of $21 \mu \mathrm{m}$ per pixel. The higher-magnification images were observed under an epifluorescent microscope (IX81 Olympus) equipped with FITC, Cy3, Dapi, and infrared $680 \mathrm{~nm}$ filters for multichannel images that were acquired with two image analysis programs (CellM, Olympus or MorphoPro, Explora-Nova). To eliminate possible autofluorescence in cortex tissue the sections were treated before slice mounting with a solution of $1 \%$ Sudan Black II in a solution of $70 \%$ ethanol (Fig. S2).

\section{Histological observation and quantification}

Drawings and cell counting of immunostained sections were made with an Olympus BX40 epifluorescence microscope equipped with a motorized $X-Y$-sensitive stage and a video CDD camera connected to a computerized image analysis system (Explora Nova, La Rochelle, France). Images were acquired using three software programs (Mosaic, Morpho Expert, and Fluo3D; Explora Nova) that apply the same contrast and time exposition for acquisition to objectively compare series of staining. The images were then generated in tiff format to be included in figure with Adobe Photoshop CS4 (San Jose, CA). Representative $50-\mu \mathrm{m}$ slices separated by $5 \mathrm{~mm}$ were used (seven sections per animal, $n=2$ ). For each section, five cortical columns were drawn and the layers were outlined for each column. The threshold for DAB staining and the cell surface limits from $50-500 \mu^{2}$ were applied to automatically identify all DCX-positive cells. The threshold of Mayer nuclei staining and the limit of nuclei surface from 10-80 $\mu^{2}$ were applied to automatically identify all cells (Mercator, Explora Nova). A visual control for these DCXpositive cells and nuclei identifications was done on 20 of 260-300 fields per column. The obtained visual counts confirmed the accuracy of the automatic counting method for determining the percentage of DCX-positive cells compared to total cells in the layers and columns.

\section{Western blot}

Total homogenates were obtained from human cortex cryosections and held in RIPA lysis buffer (Santa Cruz Biotechnology). The protein concentration was quantified using the Pierce BCA Protein Assay Kit (Thermo Fisher Scientific Waltham, MA). Ten $\mu$ g were loaded per well on Nupage 4-12\% Bis Tris gel (Invitrogen, Life Technology, Carlsbad, CA), run at $200 \mathrm{~V}$ constant and transferred on PVDF membrane (PerkinElmer, Zaventem, Belgium). The 
membranes were first incubated in Odyssey Blocking Buffer (OBB) (LI-COR), then with antibodies against DCX (the same as for immunohistochemistry) and Actin (Mouse AC74, Sigma-Aldrich), all diluted in OBB at $1 / 2,000$. The membranes were then washed three times in PBS for 10 minutes and incubated with appropriate secondary antibodies conjugated with AlexaFluor 680 dye (Invitrogen, Life Technology) or with IRDye 800 (Rockland Immunochemicals, Gilbertsville, PA). After three washes with PBS the membranes were scanned with the infrared system Odyssey (LI-COR).

\section{Reverse-transcription polymerase chain reaction (RT-PCR)}

Total RNA from fresh slice fractions and pellets of cells was extracted with Trizol (Invitrogen) and $200 \mathrm{ng}$ total RNA was used for first strand synthesis using MulVRTM0253S (New England Biolabs, Beverly, MA) as described by the supplier. PCR was performed with Polymerase Kit (Qiagen, Chatsworth, CA) with $5 \mathrm{pmol}$ of specific primers per reaction. The specific primers for DCX and nestin were designed to amplify the mRNA 1021-1494 (Access. No. AJ003112) and 714-1433 (Access. No. X65964) human sequences respectively and were homologous for the corresponding 1021-1494 (Access. No. XM_001100519) and 850-1567 (Access. No. AY650322) monkey sequences. For actin mRNA as control, two primer panels were used to amplify the 375-1154 (Access. No. X00351) human sequence and the 197-906 (Access. No. AB004047) monkey sequence. All specific forward and reverse primers for RT-PCR were designed on different exons to avoid any genomic contamination. All PCRs were performed in the Personal Thermocycler (Biometra, Germany) with one first denaturation step (3 minutes, $\left.94^{\circ} \mathrm{C}\right)$, followed by 35 cycles of denaturation $\left(94^{\circ} \mathrm{C}, 30\right.$ seconds), annealing $\left(60^{\circ} \mathrm{C}, 30\right.$ seconds), and elongation $\left(72^{\circ} \mathrm{C}, 60\right.$ seconds) and a final extension step $\left(72^{\circ} \mathrm{C}, 10\right.$ minutes). The linearity of the amplifications through 35 cycles was controlled as previously described (Waselle et al., 2009). The infrared fluorescent nucleic acid dye Syto60 (Molecular Probes, Eugene, OR) was incorporated within the loading buffer $(1 / 6,000)$ in order to detect and quantify the amplicons with the Odyssey infrared imaging system (LI-COR) after migration on a $0.8 \%$ agarose gel. To confirm the specificity of the mRNA RT-PCR amplification, amplicons were subcloned with pGEM-T easy vector system I (Promega, Madison WI) and sequenced.

\section{Incorporation of BrdU}

The proliferation marker bromodeoxyuridine (BrdU; Sigma-Aldrich) was used to investigate the specific phe- notype of the proliferating cells. As positive controls, glioblastoma cell lines (LN308) were used in the same conditions for BrdU incorporation as human and nonhuman primate adult brain cell primoculture. At the three timepoints (6 days in vitro [DIV], 28 DIV, and 35 DIV) of the cell culture, the adult brain cells were incubated 24 hours before PAF fixation with a $5 \mu \mathrm{M}$ final concentration of BrdU added to the culture medium. The BrdU was detected after a pretreatment with $\mathrm{HCl} 2 \mathrm{~N}$ for 2 minutes. The immunocytofluorescence was done with mouse antiBrdU antibody (744, Dako, Glostrup, Denmark), rabbit anti-DCX antibody (ab18723 Abcam) and chicken anti GFAP (AB5541, Chemicon) and the appropriate fluorochrome conjugated secondary antibodies against mouse Ig (Alexa 488, A-1 1032 Invitrogen, Life Technology), rabbit Ig (Alexa 594, A-11034 Invitrogen, Life Technology), and chicken Ig (IRDye 700, 603-130-126, Rockland Immunochemicals). The nuclei were counterstained with DAPI. Immunostained cells were observed using an epifluorescent microscope IX81 (Olympus).

\section{Cell counting of BrdU-positive cells}

Cell counting per coverslip was determined by the sum of four fields on one coverslip. The total cell number was determined by counting DAPI-counterstained nuclei. The colocalization of BrdU with other markers such as GFAP or DCX were done by co-immunocytofluorescence before counting. The mean of cell number was established with the six independent cell cultures from three patient biopsies.

\section{RESULTS}

All data derived from the brain of two species of nonhuman primate (cynomolgus monkeys (Macaca fascicularis) and St. Kitts green monkeys (Chlorocebus sabaeus) were identical and therefore are presented below together.

\section{DCX-positive cells are present in nonhuman primate neocortex}

In the nonhuman primate cerebral cortex, the immunohistochemical analysis showed that the expression of DCX was not restricted to the subgranular zone of the hippocampus or to the subventricular zone but DCX was also found in the cerebral cortex (Fig. 2A). This DCX expression was highly localized at the glia limitans, in layer II and layer $\mathrm{V}$ of the cortex (Fig. 2B-E). This expression was also observed in human cortex and confirmed by comparing three different sources of antibody against DCX (Supplemental Data Fig. S1). The cell counting on DAB-immunostained nonhuman primate brain sections showed that $4.55 \pm 1.58 \%$ of total cells expressed DCX in whole neocortex. In terms of percentage of positive 


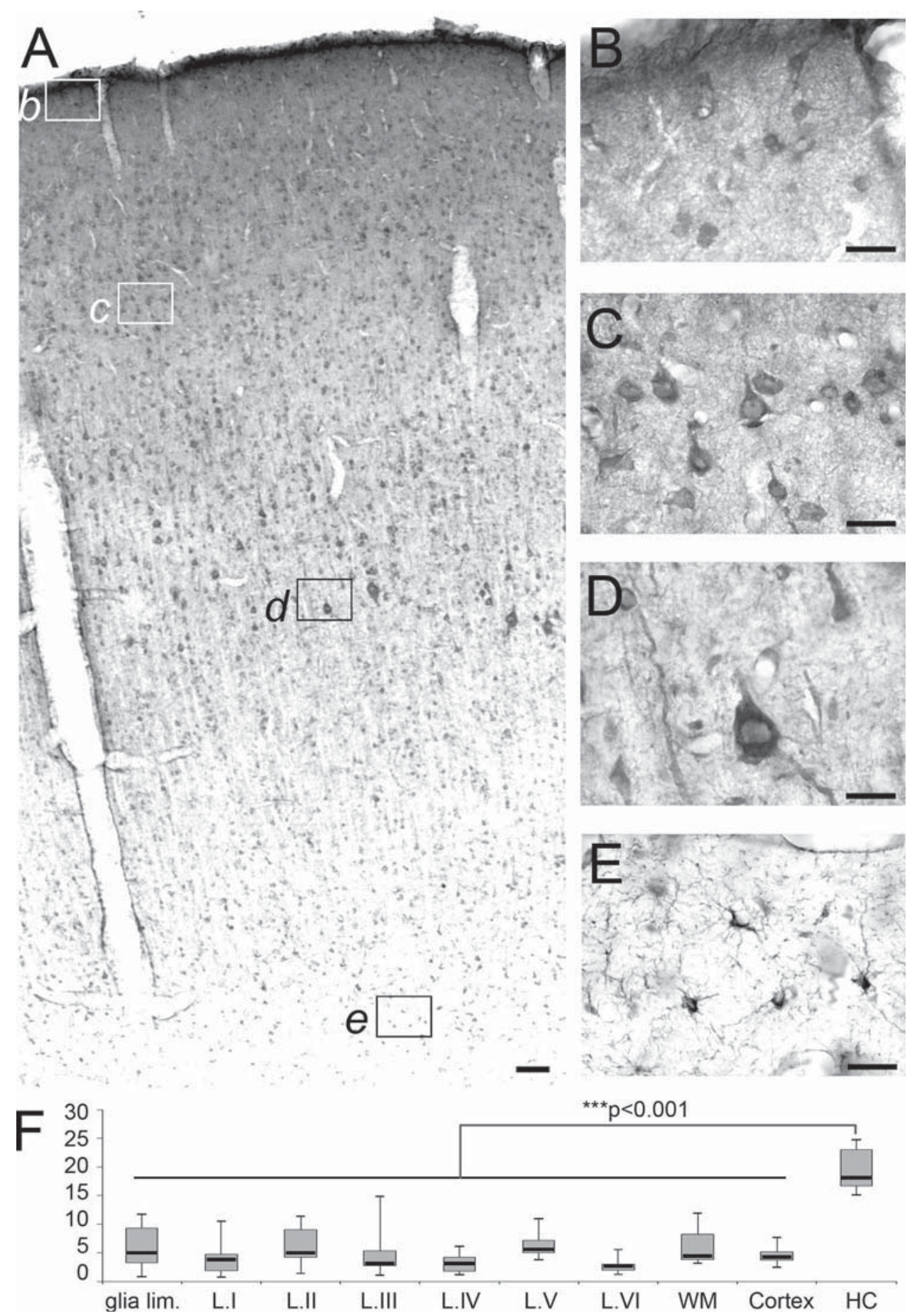

Figure 2. DCX-immunohistochemistry done on macaque brain cryosection with guinea pig antibody against DCX (Chemicon). The mosaic reconstruction (A) was a part of cerebral cortex in the right precentral gyrus at the level of superior precentral sulcus. (B-E) correspond to boxes labeled ( $b$ to e) in (A): DCX was expressed in nonhuman primate cortex, in cells with long processes in the glia limitans and layer I (B), in pyramidal cell bodies in layer II (C) and in layer V (D), and in small stellar cells at the border between GM and WM (E). The nuclei were counterstained with Mayer's hematoxylin solution (MHS32, Sigma-Aldrich). Note that this DCX distribution was through all the neocortex with no significant difference in intensity or density. F: Distribution of DCX-positive cells in the cortical layers. The counts for DCX and total nuclei were done in 35 cortical columns ( 5 columns per section, 7 sections per animal, $n=2)$ ) and in 12 areas of hippocampal subgranular zone $(\mathrm{HC})$ ( 3 areas per section, 4 sections). The first eight boxplots represent the distribution in the glia limitans, the six cortical layers, and the white matter next to the gray. The "whole cortex" boxplot corresponds to the pooled counts in all layers. The results are expressed in percentage of DCX-positive cells versus total nuclei. Note that there was no significant difference between cortical layers, whereas there were significantly fewer DCX-positive cells (nearly 4-fold less) in cortical structures compared with the subgranular zone of hippocampus (analysis of variance [ANOVA], Bonferroni multiple comparison ${ }^{* \star} P<0.001$ ). Scale bars $=100 \mu \mathrm{m}$ in A; $25 \mu \mathrm{m}$ in B-E. 


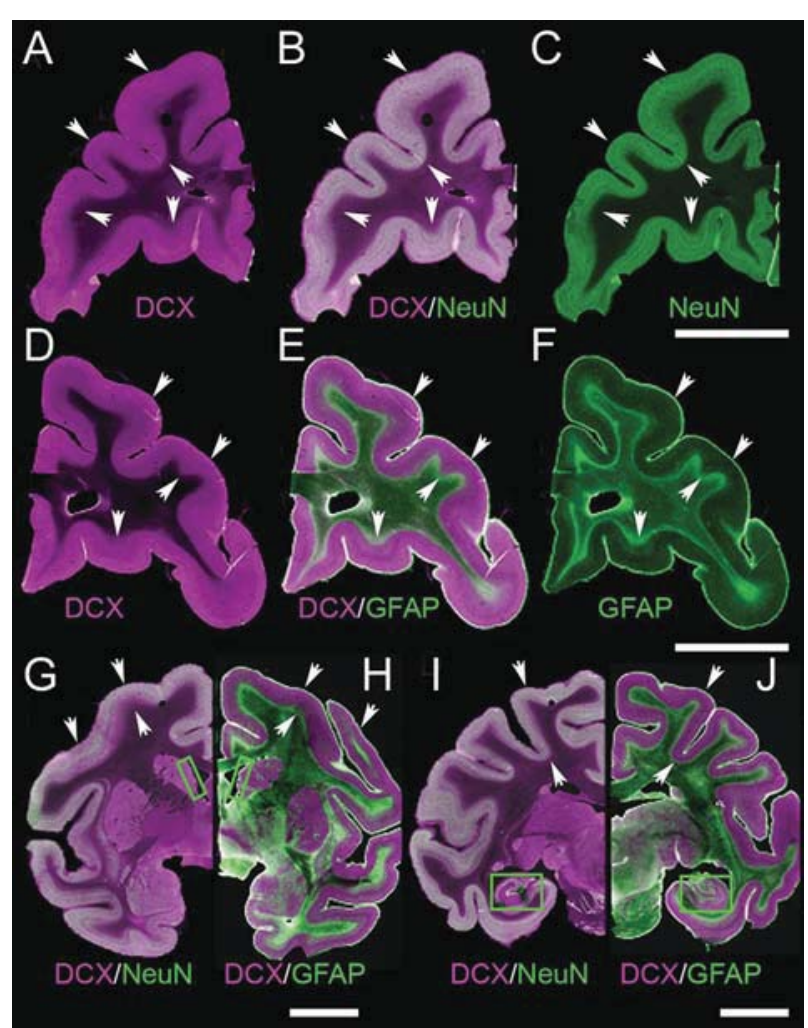

Figure 3. Coronal sections of St. Kitts green monkey brain infrared immunostained for DCX (guinea pig antibody, Chemicon) and GFAP or DCX and NeuN detected with Odyssey Infrared scanner (LICOR) at a resolution of $21 \mu \mathrm{m}$ per pixel. Fixed monkey brain sections were cut in two half-sections, one incubated with guinea pig anti-DCX and mouse anti-NeuN antibodies and the second one incubated with guinea pig anti-DCX and rabbit anti-GFAP antibodies followed by the appropriate infrared fluorochrome conjugated secondary antibodies (see Materials and Methods). The left frontal cortex half-section was immunostained for DCX (in magenta pseudocolor (A)) and NeuN (in green pseudocolor (C)) with the overlay (B); the right frontal cortex half-section was immunostained for DCX (in magenta pseudocolor (D)) and GFAP (in green pseudocolor $(F)$ ) with the overlay (E). (G,I) Only the overlays obtained as in (B) and $(\mathrm{H}, \mathrm{J})$ as in (E) for more caudal sections; the green squares outline the subventricular zone in $(\mathrm{G}, \mathrm{H})$ and the hippocampus in $(I, J)$, respectively. Note that if the main DCXimmunostaining is colocalized with NeuN, the glia limitans and the limit between white and gray matter (white arrows) also presents colocalization. Also note that DCX is detectable in whole cortex from frontal to occipital lobes. Scale bars $=1 \mathrm{~cm}$.

cells, no significant differences were observed between cortical structures or between cortical layers (Fig. 2F). Furthermore, this percentage of DCX-positive cells is significantly lower (near 4-fold) in cortical structures than in the hippocampal subgranular zone, where $19.62 \pm 3.74 \%$ of cells were DCX-positive. Higher magnifications showed that the cells expressing DCX were not shaped homogeneously; indeed, DCX-positive cells with long processes were observed in the glia limitans and in the layer I (Fig. 2B),

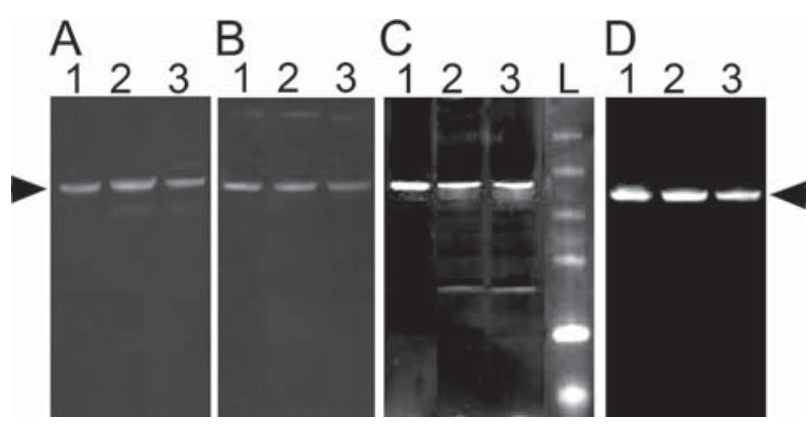

Figure 4. Western blot done with three polyclonal antibodies against DCX: (A) rabbit antibody (ab187723, Abcam); (B) guinea pig antibody (AB2253, Chemicon); (C) goat antibody (sc-8066 Santa Cruz Biotechnology); and (D) actin (Mouse AC74, SigmaAldrich). The western blot was done with one homogenate done with normal adult human brain cortex biopsy (lane 1), and two homogenates done from monkey brain obtained in vitro from the WM and the GM fractions (lanes 2 and 3, respectively). L corresponds to the SeeBlue ladder (Invitrogen).

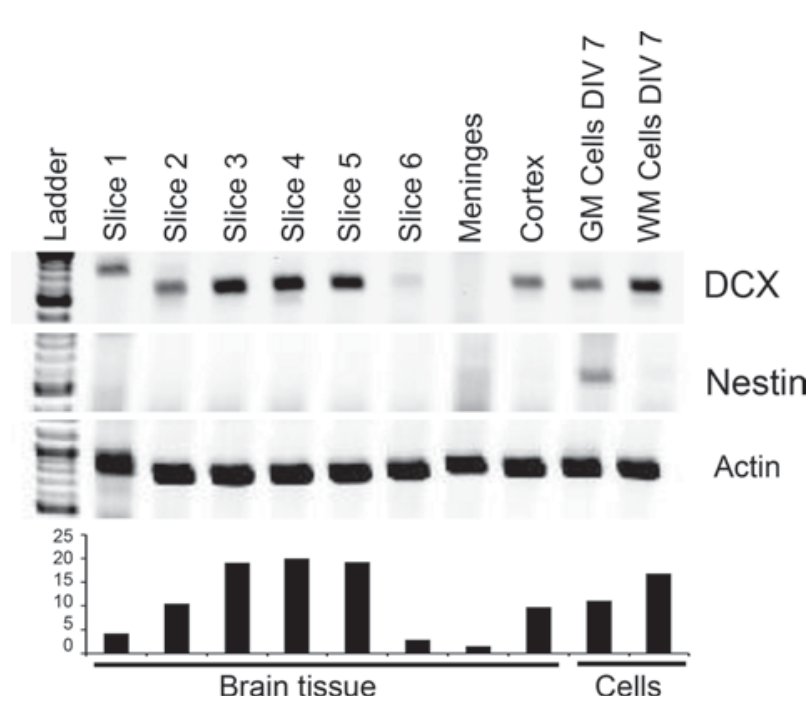

Figure 5. RT-PCR done with total RNA extracted from human neocortical layering slice-enriched fractions and from adult human brain cell cultures. DCX mRNA was present in all fractions from human cortex and in cell cultures from the first days in vitro (DIV7) except in the meninges and in the deeper WM fraction (slice 6). Nestin mRNA was not detectable under the same RTPCR conditions except slightly in the GM cell culture (DIV7). Actin mRNA was used as control to establish the relative ratio of DCX/ Actin using Syto60 infrared intensity presented in the graph at the bottom (this experiment is representative of the six slicing experiments done with four human and two nonhuman primate biopsies).

DCX pyramidal cell bodies with neuronal shapes were stained in layer II (Fig. 2C) and V (Fig. 2D) and small stellar DCX-positive cells were located at the limit between GM and WM (Fig. 2E). The immunohistofluorescence to detect 


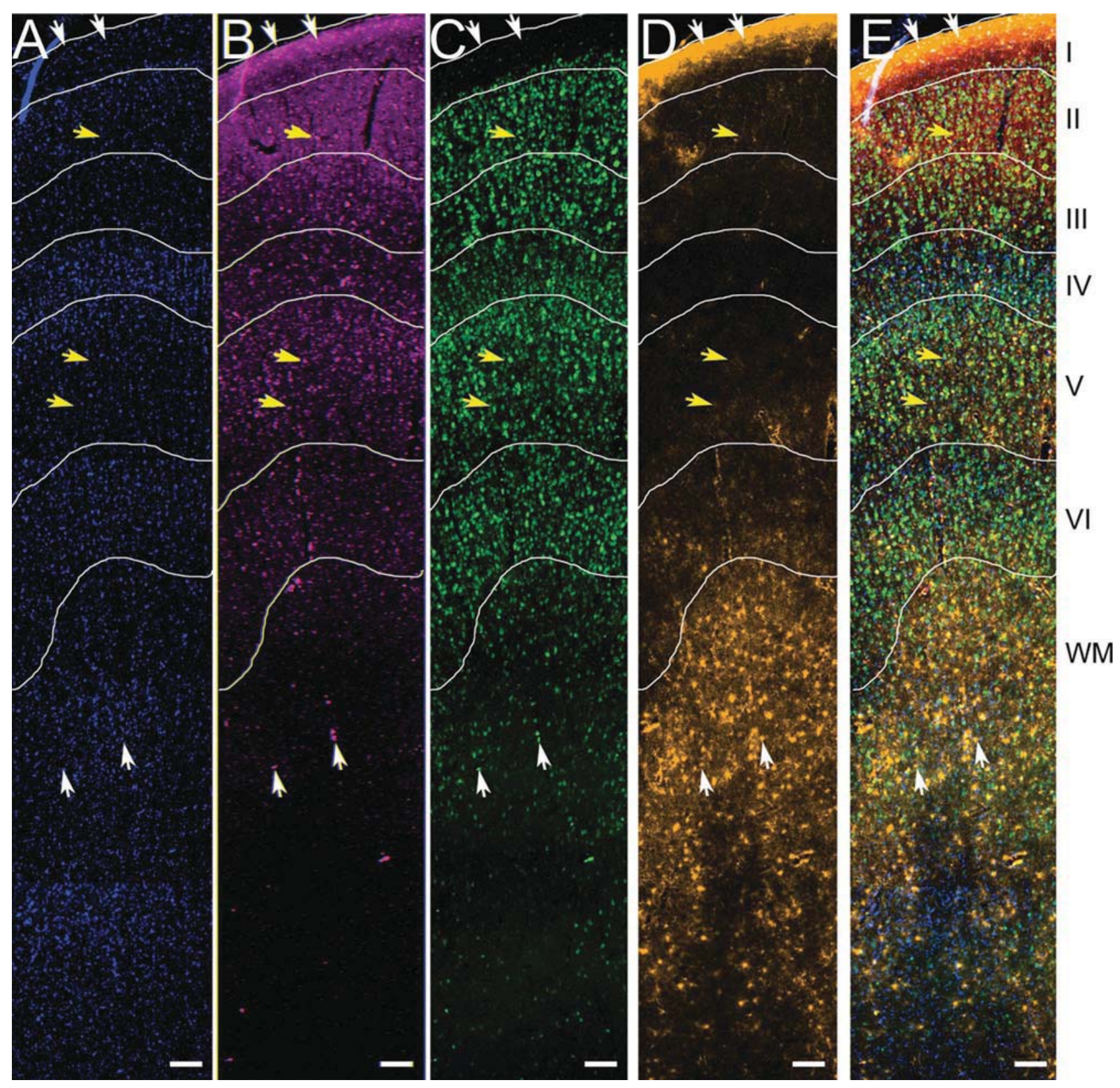

Figure 6. A: Mosaic reconstruction of the Chlorocebus neocortex triple immunofluorostaining for DCX (rabbit antibody, Abcam), NeuN and GFAP detected with Alexa 488, Alexa 594, and IRDye $700 \mathrm{~nm}$ conjugated secondary antibodies, respectively, with a counterstaining of nuclei with DAPI (in blue (A)). DCX (in magenta (B)) was mainly shown in layer I (white arrows), and in layers II and V (yellow arrows) even if it was distributed from the glia limitans (white arrows) to the limit between gray and white matter. DCX immunostaining colocalized with NeuN (in green (C)) (yellow arrows), and also with GFAP (in orange pseudocolor (D)) (white arrows). Scale bars $=100 \mu \mathrm{m}$.

DCX with the Odyssey infrared scanner showed that in addition to expression in the subventricular zone (Fig. 3C) and the subgranular zone of the hippocampus (Fig. 3D), DCX was also observed in the whole cerebral cortex (Fig. 2). It confirmed the presence of DCX from glia limitans to the limit between GM and WM in the nonhuman primate neocortex. Similar results were obtained on the cryosections derived from the five normal monkeys (three Macaca fascicularis and two Chlorocebus sabaeus). The main corti- cal expression of DCX was localized in the GM of the frontal section (Fig. 3A,B). At this resolution rate of $21 \mu \mathrm{m}$, a colocalization with NeuN could be observed at a macroscopic histological level in the cortical neuronal layers (Fig. 3A), but also with GFAP in the glia limitans and the limit between GM and WM (Fig. 3B). This pattern of nonhuman primate cortical expression of DCX has been observed through all the neocortex, even though the expression was stronger in the subventricular zone and in 

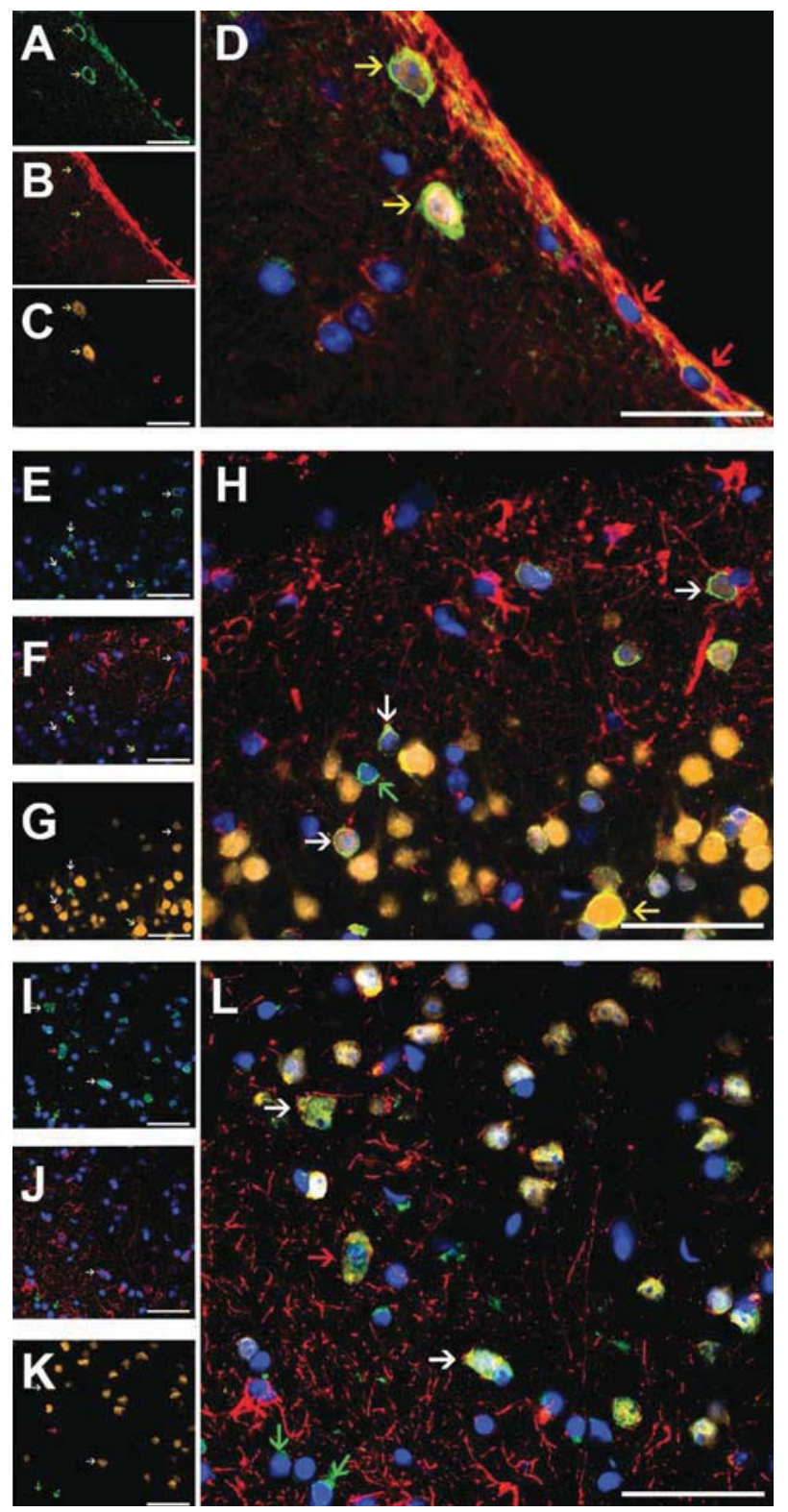

Figure 7. Higher magnification of the Chlorocebus neocortex triple immunofluorostaining for colocalization of DCX (rabbit antibody, Abcam) revealed in green $(A, E, I), G F A P$ in red $(B, F, J)$, and NeuN in orange pseudocolor $(C, G, K)$ on $5-\mu m$ paraffin sections; $(D, H, L)$ show the overlays of $(A-C),(E-G)$, and $(I-K)$ respectively, with the nuclei counterstained with DAPI in blue. Note that a subpopulation of DCX-positive cells coexpressed NeuN (yellow arrows) in layer I (A-D), in layer II (E-H), and layer V (I-L); another one coexpressed GFAP (red arrows) in the glia limitans (A-D) and at the limit between GM and WM (I-L); a third one coexpressed NeuN and GFAP (white arrows); and a fourth subpopulation did not express NeuN nor GFAP (green arrow) in layer II $(\mathrm{E}-\mathrm{H})$ and in layer $\mathrm{V}(\mathrm{I}-\mathrm{L})$. (See also Supplemental Data Figs. S2, S3.) Scale bars $=50 \mu \mathrm{m}$. the subgranular zone of the hippocampus (Fig. 3C,D). DCX was expressed in whole cortex and the comparison of the infrared DCX-immunolabeling intensities revealed no significant difference between the different cortical areas. The expression of DCX was also confirmed by western blot (Fig. 4A-C) done with one adult human cortical homogenate and two monkey brain homogenates obtained from WM and GM fractions, and the same bands were revealed with rabbit (Abcam), guinea pig (Chemicon), and goat (Santa Cruz) immunoglobulins against DCX (Fig. 4A$C$; note that $D$ represents the actin expression as control for western blot loading).

By RT-PCR done with the "slicing" procedure (Fig. 1), the DCX mRNA was detected in the human neocortex, with a significantly higher expression in slices 3 , 4, and 5 that mainly corresponded to the topography of layer IV and to the limit between GM and WM (Fig. 5). The specific forward and reverse DCX primers were designed on exons 3 and 7 of the human gene sequence, respectively; the size corresponded to the DCX mRNA sequence. For three RT-PCR samples (one human and two monkeys), the amplicons were subcloned, sequenced, and confirmed the complete homology with the DCX sequence. With the same samples, under the same RT conditions, the PCR for nestin did not reveal the presence of nestin mRNA in cortical slices. However a slight nestin expression was detected in the GM cell culture after 7 days.

\section{DCX is expressed in astrocytes and neurons in nonhuman primate cortex}

To identify the cell subtypes of DCX-positive cells revealed by immunohistochemistry, co-immunofluorescence labeling was performed using the rabbit antibody against DCX (Abcam). The same pattern was observed with this rabbit anti-DCX antibody compared to that from the guinea pig (Fig. 6). The mosaic reconstruction of the cortex exhibited the same layer distribution of DCX. Cell counting on triple immunofluorescence-stained sections gave the same percentage, $4.33 \pm 1.48 \%$ of DCX-positive cells versus total cells in a cortical column as shown above with DAB staining. Higher magnification demonstrated the presence of four subpopulations of DCX-positive cells (Fig. 7). First, small cells only expressed DCX and represented $17.85 \pm 4.32 \%$ of the total DCX-positive cells. The cells that only expressed DCX presented long processes and small nuclei. No co-localizations were observed with Iba1 (microglia/macrophage marker), nestin (neural progenitor/stem cell marker), or vimentin (glial progenitor marker) (data not shown). Second, $26.24 \pm$ $3.31 \%$ of the DCX-positive cells coexpressed NeuN and represented $2.89 \pm 1.18 \%$ of the total NeuN positive cells. The DCX-positive cells that coexpressed NeuN in layer I (Fig. 7A-D) presented the typical shape of the 


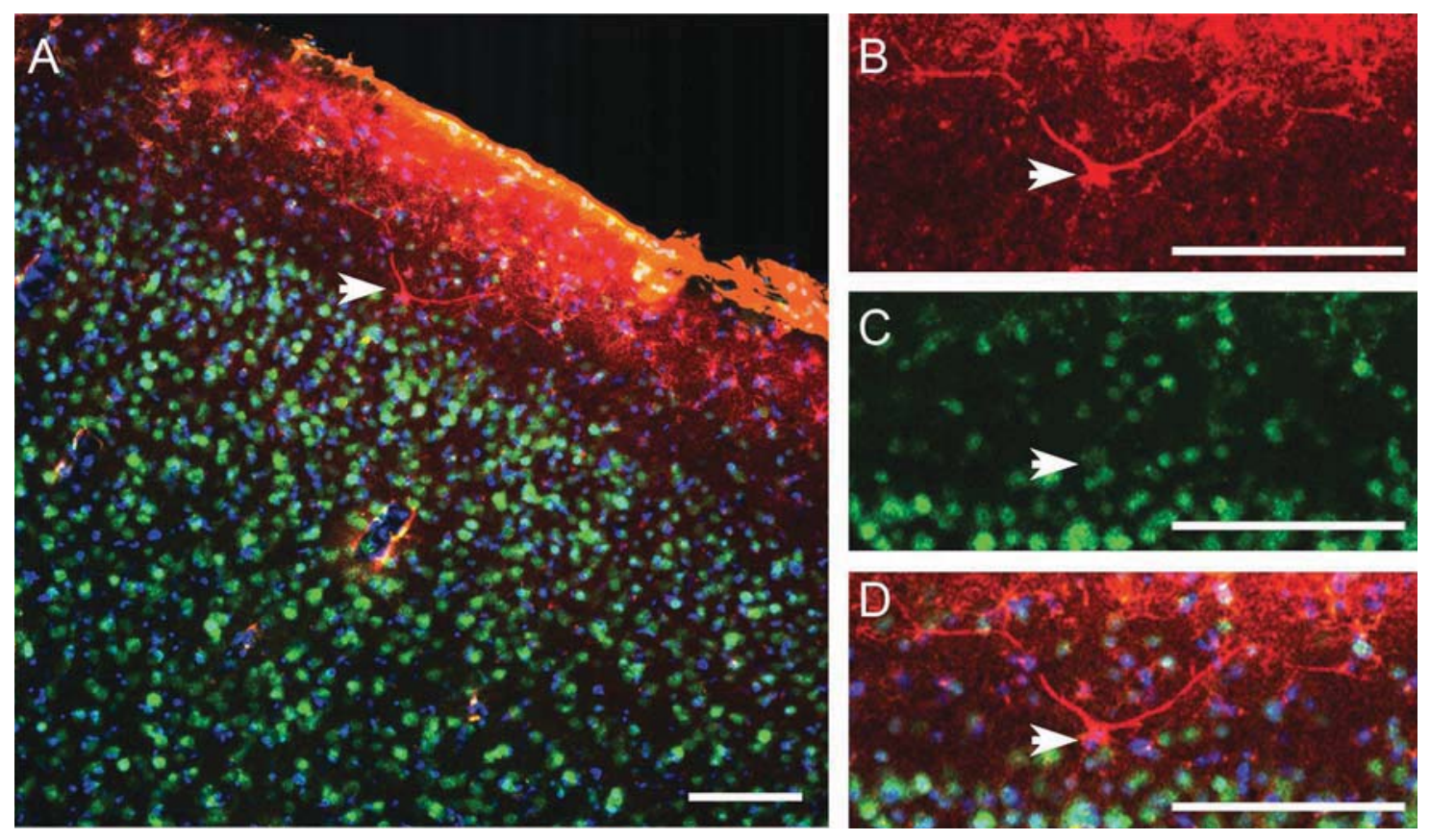

Figure 8. The Chlorocebus neocortex triple immunofluorostaining on $50 \mu \mathrm{m}$ floating prefrontal cortex cryosection for colocalization of DCX (rabbit antibody, Abcam) in red (B), NeuN in green (C), and in the overlay (A) GFAP in orange with the nuclei counterstained with DAPI in blue (A-D). The higher magnifications (B-D) show a cell that coexpressed NeuN and DCX (white arrows) and presented the typical shape of the Cajal-Retzius cells. Scale bars $=100 \mu \mathrm{m}$.

Cajal-Retzius cells (Fig. 8). In layers II and V the DCXNeuN positive cells exhibited a pyramidal neuronal shape (Figs. 2, 7E-H). Third, $26.44 \pm 6.03 \%$ of the DCX-positive cells coexpressed GFAP and represented $11.66 \pm 4.06 \%$ of the total GFAP-positive cells. The DCX-GFAP positive cells also presented two types of shape. In the glia limitans, these DCX-GFAP-positive cells had long processes but, at the border between GM and WM, they were small stellar cells (Fig. 7I-L). Fourth, $29.47 \pm 7.07 \%$ of DCXpositive cells surprisingly coexpressed NeuN and GFAP. Notably, $92.85 \pm 5.80 \%$ of the total GFAP and NeuN-positive cells expressed DCX (Fig. 7).

\section{DCX-positive cells are present in adult brain cell cultures from human brain biopsies}

The DCX mRNA was detected in adult human brain cells from the first days in vitro when nestin was only slightly or not detectable (Fig. 5). The immunocytofluorescence also revealed the presence of DCX in cells after DIV 10. At different timepoints the progression of the cell culture and the expression of DCX were investigated. The cell quantification by infrared Syto 60 nucleus labeling showed that only enriched cell suspensions that contained DCX-positive cells, cortical slices 1 and 3, and the WM and GM fractions were able to survive over time (Fig. 9J). Slice 4, which included a deeper cortical layer and the limit between GM and WM, did not present viable cells over time. Slice 2, which presented only few DCXpositive cells at DIV 10, rapidly degenerated with no survival over time (Fig. 9D-F). Slices 1 and 3, the enriched GM fraction and the enriched WM fraction that presented DCX-positive cells, maintained a substantial population of cells that survived over time and formed adult brain cell aggregates (Fig. 9A-C,G-I).

The incorporation of BrdU revealed that some cells were in S phase over 24 hours (Fig. 10). Fewer than 25 positive cells per field were detected for BrdU from normal WM and GM fractions. This number did not change over time but the population continued to increase to a total of 45 cells per field at DIV 7, of 280 cells per field after 28 days. At 35 days, the percentage of BrdU-positive cells only represented $9.8 \%$ despite 24 hours of exposure to BrdU (Fig. 10). Nearly all the BrdU-positive cells expressed DCX and GFAP (white arrow, Fig. 10), although they were at the metaphase stage of mitosis (yellow arrow, Fig. 10A-E). The LN308 glioma cell line was used as the positive control for BrdU incorporation (Fig. 11) and showed that 69.2\% per field of nuclei incorporated BrdU over 24 hours.

\section{DISCUSSION}

In the present study we demonstrated the expression of DCX in the cerebral cortex of adult humans and two species of monkeys. We discovered four different populations of DCX-positive cells. Indeed, the DCX- 

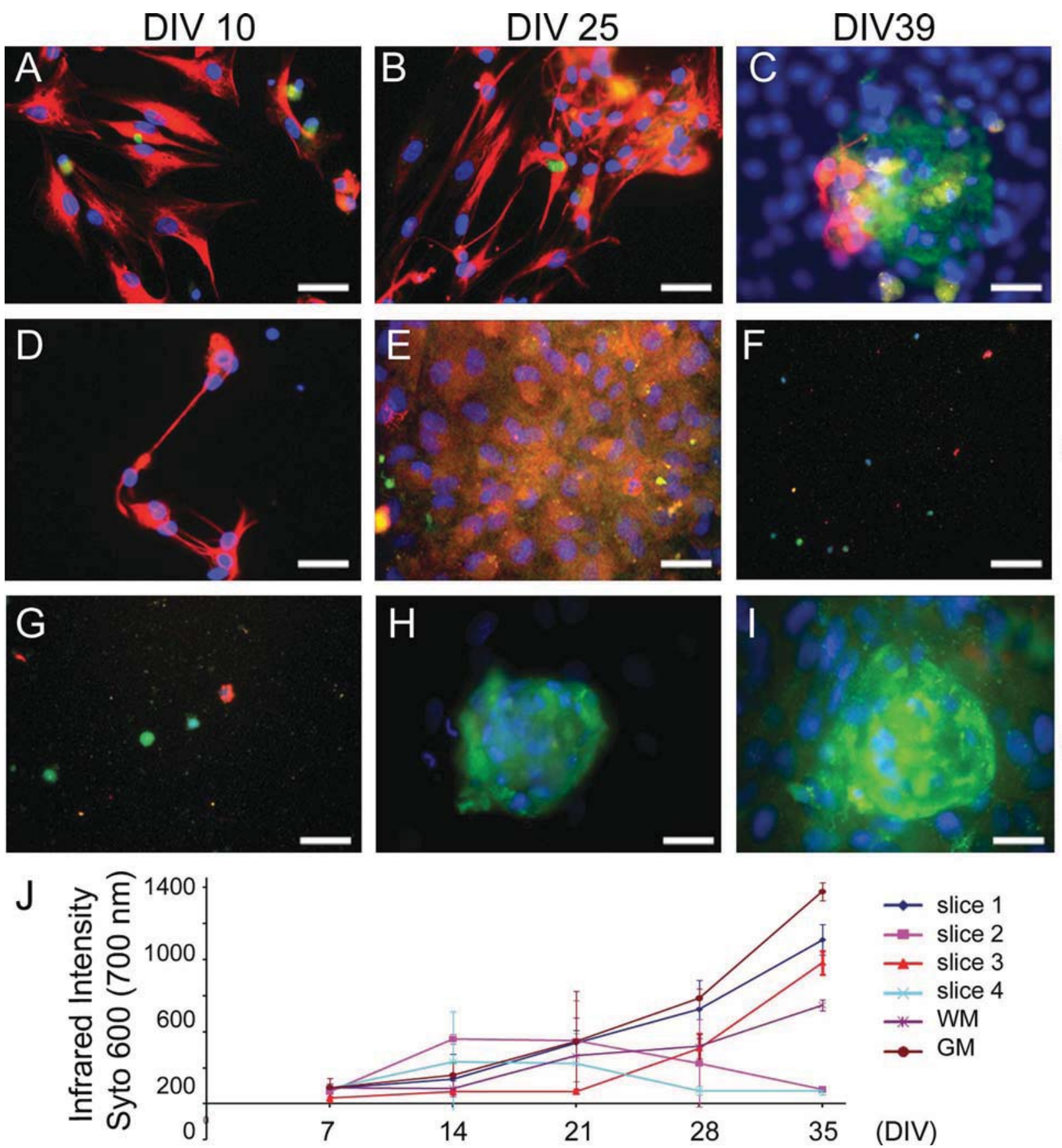

Figure 9. Cell culture from neocortical layering slice enriched fractions immunostained for GFAP (in red) and DCX (guinea pig polyclonal antibody, Chemicon) (in green) with a counterstaining of nuclei with DAPI (in blue). (A-C): slice 1 culture; (D-H): slice 2 culture; and (G-I): slice 3 culture each shown at three different timepoints: DIV 10, 25, and 39. In slices 1 and 3 the presence of DCX-positive cells is detected at all timepoints and the DCX population increases over time. After DIV 25, GFAP is just detected in a very few cells. (J): The cell quantification done with the infrared DNA dye Syto60 showed that only enriched cell suspensions from slice 1, slice 3, WM and GM fractions were able to survive over time. Note that these fractions contain DCX-positive cells in the early stage of culture. Scale bars $=$ $50 \mu \mathrm{m}$.

immunoreactivity was localized in all the cerebral cortical layers from the glia limitans and around the limit between WM and GM. The DCX-positive cells had different shapes: in layer I they presented the typical shape of the CajalRetzius cells; in layers II and V they exhibited a pyramidal neuronal shape. In the glia limitans they presented long processes, whereas at the border between GM and WM they were small stellar cells. We also demonstrated, using mRNA and protein quantification, that DCX was detectable in all of the human neocortical tissues. The detection 
of DCX mRNA was performed by RT-PCR, which is more sensitive than Northern blot (Omori et al., 1998).

Moreover, we demonstrated that the four DCX-positive cell populations were colocalized, with different neuronal and glial markers depending on their location in the cortex: in layers I, II, and V the DCX-positive cells expressed NeuN, whereas in the glia limitans and around the limit between WM and GM the DCX-positive cells coexpressed GFAP. In the glia limitans the DCX-positive cells with long processes expressed GFAP and in the border between GM and WM the small stellar DCX-positive cells also expressed GFAP. The cells that only expressed DCX presented long processes and small nuclei.

DCX-positive cells have been described in the neurogenesis niches of adult rodents (Brown et al., 2003; Couillard-Despres et al., 2005; Rao et al., 2005), but they were never detected in cortex except in the rat piriform cortex where DCX was colocalized with NeuN, suggesting an involvement in axonal or synaptic plasticity (Nacher et al., 2001). Compared with total cell density, DCX-positive cells were significantly less numerous in the cortex than in the neurogenic subgranular zone of the hippocampus. Nevertheless, DCX-positive cells in the cerebral cortex represented a significant population, amounting to $\approx 4-$ $5 \%$ of all cortical cells. Furthermore, they were evenly distributed among the four identified populations of DCXpositive cells. This large distribution over the whole cortex and subcortical areas would be related to the greater ability to elaborate interconnectivity between cortical structures in the more highly evolved simians and humans. We hypothesize that this wide distribution of $\mathrm{DCX}+$ cells may have a close relationship with mammalian evolution, as brain size has gradually increased (for review, see Bradbury, 2005), in particular the cerebral cortex of the more evolved species (for review, see Levitt et al., 1997). Monkeys and humans have far more cortex than rodents, and this enlarged cortex is associated with much slower development (Allman et al., 1999). It may be that DCX expression, which is a feature of immature neurons, is an example of the retention of a juvenile trait of an ancestor in the adults of the descendants, also known as a "pedomorphic" feature (Gould, 1992). The persistence of CajalRetzius cells in adult human cerebral cortex as already described (Martin et al., 1999) could also be another argument for this hypothesis since some cells that coexpress DCX and NeuN present the typical Cajal-Retzius cell shape.

The evidence suggests now that the DCX cortical cells are not stem cells, but they may have a neural progenitor potential (Goldman et al., 1997; Palmer et al., 1999; Bjorklund and Lindvall, 2000; Arsenijevic et al., 2001; Brunet et al., 2002, 2005). These cells were certainly present at the origin of the adult brain cell culture we obtained in vitro with simian and human cortex; however, this finding could not be reproduced with rodent brains, where no DCX cortical cells could be detected. In this report we demonstrate that the cells obtained in vitro expressed DCX at the beginning of the culture. When the cortex was sliced in layers, only the layers containing DCX-positive cells were able to give viable cells over time. The BrdU incorporation showed that only a few cells were dividing and they expressed DCX and GFAP. The number of dividing cells did not increase over time, which suggests an asymmetric division. A dividing cell would generate a quiescent progenitor cell that still expresses DCX but not GFAP and a new dividing cell that expresses DCX and GFAP. These proliferating cells were closely associated with cells that have long GFAP-positive processes. This association of these cell types, which was essential for the development of the culture over time, should recreate the stem cell-like niche in vitro. This niche, with few astrocytes that surround numerous DCX and DCX/GFAP progenitors, represents an interesting tool for cell therapy, since the astrocytes protect through cell contact and "survival" factor delivery. We have already demonstrated the important rate of survival of such cells after autologous reimplantation and their ability to migrate and to differentiate into neurons in motor cortex lesions in monkeys (Brunet et al., 2005) or to limit the TH depletion in asymptomatic MPTP parkinsonian monkeys (Brunet et al., 2009). These posttransplantation abilities would also depend on the cell-cell interaction and the progenitor properties of these cells as described in this report.

In conclusion, the presence of DCX-positive cells and the ability to produce precursor cell cultures from the primate cortex were demonstrated to be closely linked, even if the cellular origin of the in vitro cells has to be

Figure 10. Immunostaining for BrdU (in green), GFAP (in yellow pseudocolor), and DCX (rabbit antibody, Abcam) (in magenta) with a counterstaining of nuclei with DAPI (in blue). A-E: WM cells in vitro (case 173 DIV35); F-J: GM cells in vitro (case 173 DIV28). These two panels show the detection of $\operatorname{BrdU}(A, F), \operatorname{DCX}(C, H)$, GFAP $(D, I)$, and Dapi $(B, G)$ and the overlay of the four color pictures (E,J). The BrdUpositive cells from normal WM and GM fractions expressed DCX and GFAP (white arrows) even if they were at the metaphase stage of mitosis (yellow arrow). K: Quantification at three timepoints of DCX+GFAP+BrdU+ cells compared to BrdU+ cells and total cells. Results are expressed by means and standard deviations of cell number per field $\left(n=3\right.$ cases, five fields were counted per case, ${ }^{* \star *} P<0.001$, the two last points compared to the first one). Nearly all BrdU+ cells were DCX-and GFAP-positive. Note that the number of BrdU + cells did not significantly increase over time unlike the total cell number. Scale bars $=50 \mu \mathrm{m}$. 

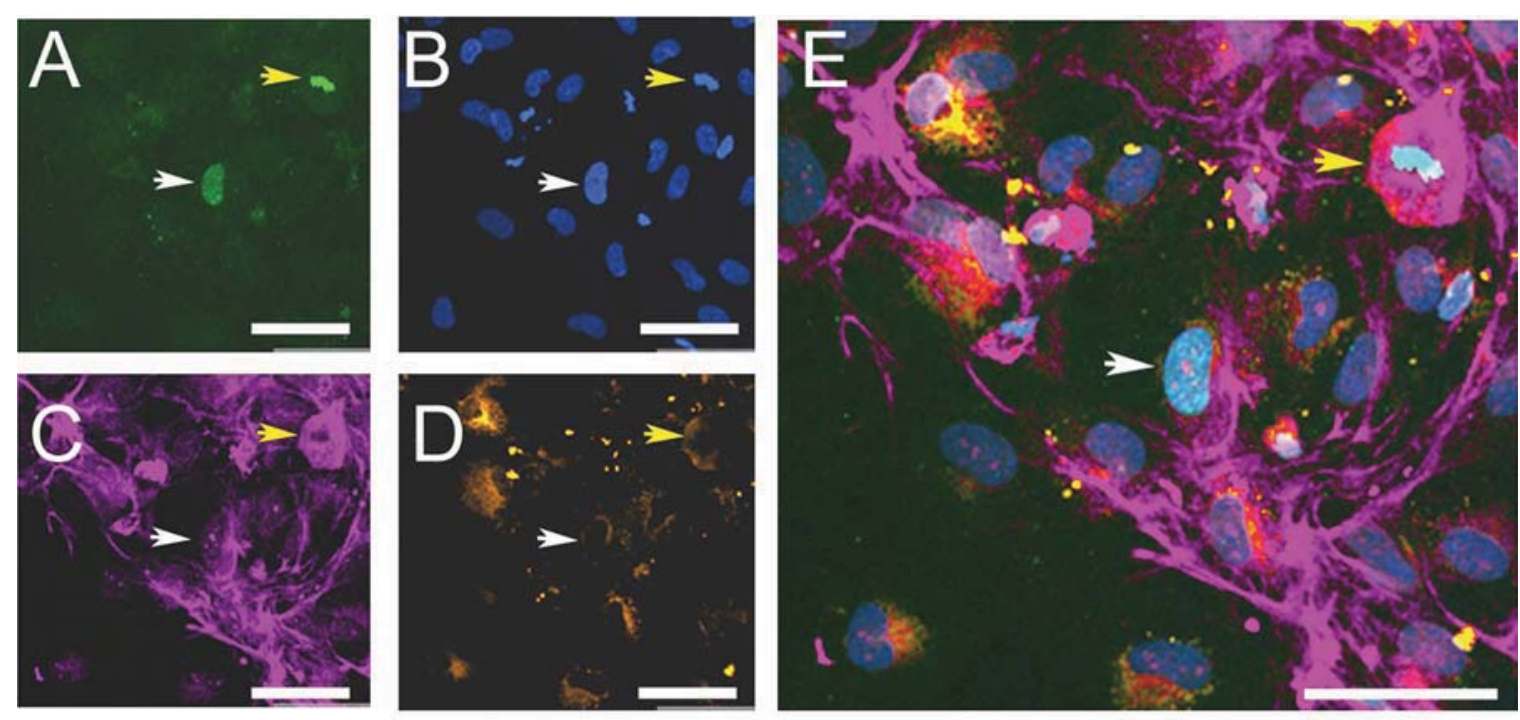

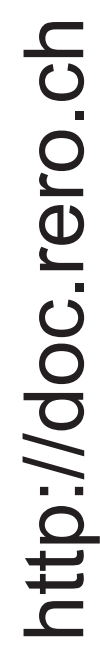
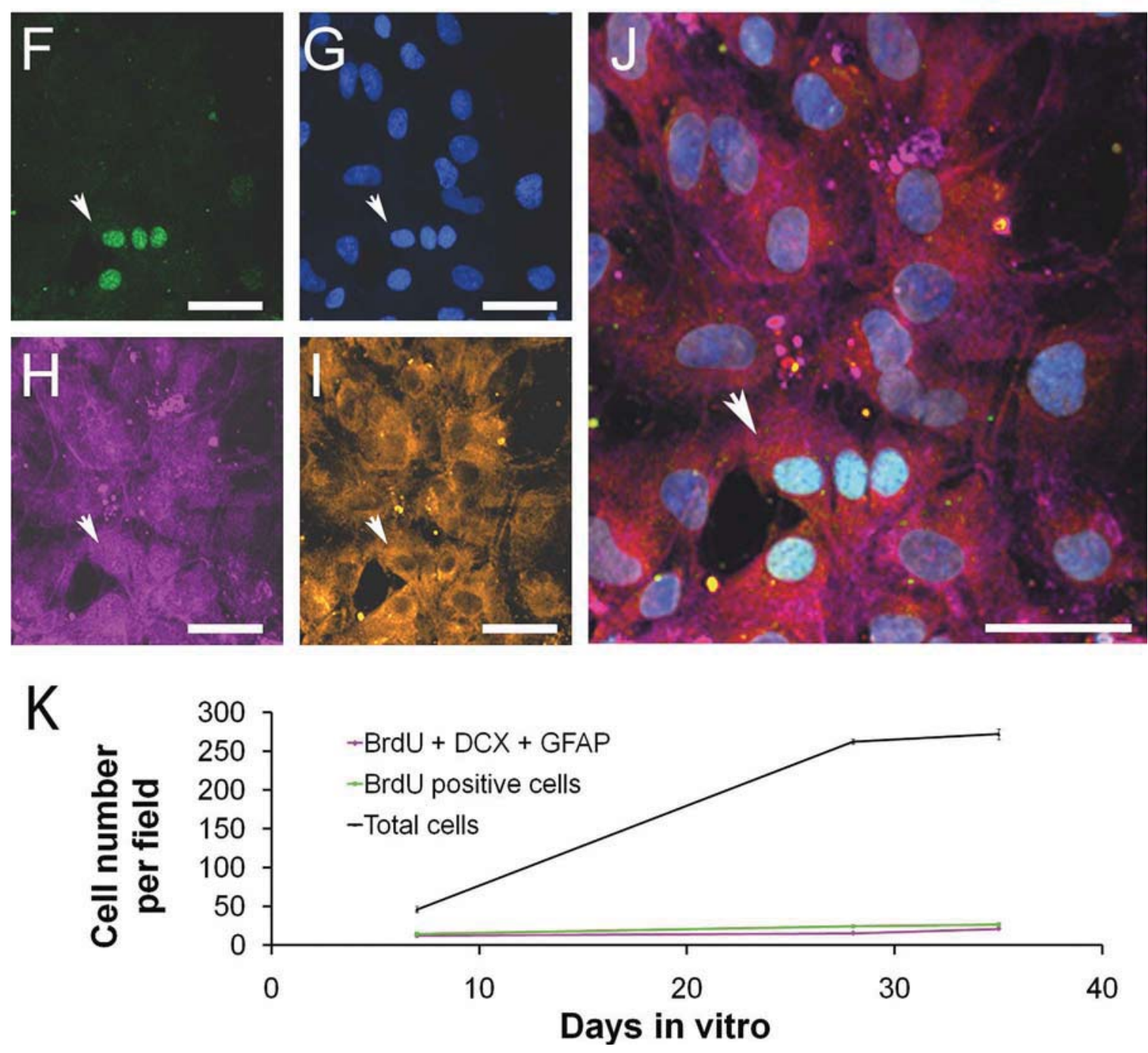

Figure 10. 

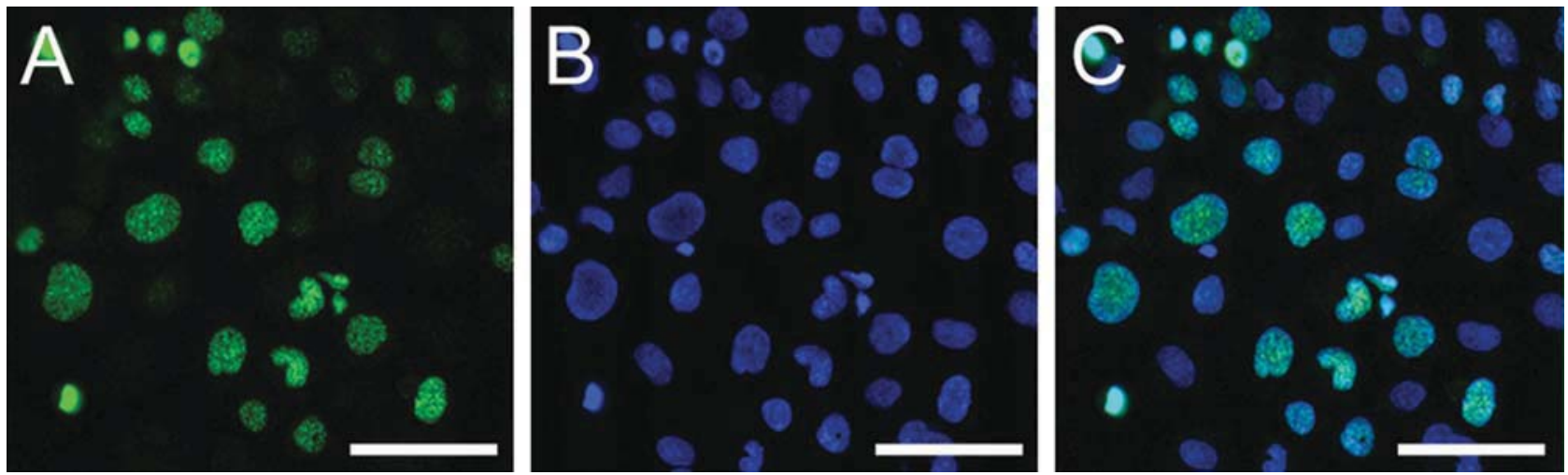

Figure 11. LN308 glioma cell line as positive control for BrdU incorporation detected for BrdU (A, in green) and Dapi (B, in blue) with the overlay (C). Note that more than $70 \%$ of cells incorporated BrdU during 24 hours. Scale bars $=100 \mu \mathrm{m}$.

clearly more clearly defined through further experiments. This specificity of adult primate DCX expression in the cortex is likely associated with the evolution of primate cortex. These DCX-positive cells should be investigated further to determine their roles in synaptic and metabolic plasticity and various neuropathologies. In the future, these cells could play an important role in brain repair as endogenous tools or as autologous transplant material after in vitro cell culture, possibly with less tumor liability and without immunogenicity.

\section{ACKNOWLEDGMENTS}

We thank Catherine Pythoud, Véronique Moret, Christine Roulin, Françoise Tinguely, and Christiane Marti (histology and behavioral evaluations), the staff of the Fribourg University Animal Facility, Josef Corpataux, Laurent Bossy, Bernard Bapst, and Bernard Morandi (animal house keeping), and the staff of the St. Kitts Biomedical Research Foundation for expert technical assistance.

\section{LITERATURE CITED}

Allman J, Hasenstaub A. 1999. Brains, maturation times, and parenting. Neurobiol Aging 20:447-454.

Arsenijevic Y, Villemure JG, Brunet JF, Bloch JJ, Deglon N, Kostic C, Zurn A, Aebischer P. 2001. Isolation of multipotent neural precursors residing in the cortex of the adult human brain. Exp Neurol 170:48-62.

Arvidsson A, Collin T, Kirik D, Kokaia Z, Lindvall O. 2002. Neuronal replacement from endogenous precursors in the adult brain after stroke. Nat Med 8:963-970.

Bedard A, Gravel C, Parent A. 2006. Chemical characterization of newly generated neurons in the striatum of adult primates. Exp Brain Res 170:501-512.

Benton RL, Maddie MA, Minnillo DR, Hagg T, Whittemore SR. 2008. Griffonia simplicifolia isolectin B4 identifies a specific subpopulation of angiogenic blood vessels following contusive spinal cord injury in the adult mouse. J Comp Neurol 507:1031-1052.

Bernier PJ, Bedard A, Vinet J, Levesque M, Parent A. 2002. Newly generated neurons in the amygdala and adjoining cortex of adult primates. Proc Natl Acad Sci U S A 99: 11464-11469.

Bjorklund A, Lindvall O. 2000. Self-repair in the brain. Nature 405:892-893, 895.

Bradbury J. 2005. Molecular insights into human brain evolution. PLoS Biol 3:e50.

Brown JP, Couillard-Despres S, Cooper-Kuhn CM, Winkler J, Aigner L, Kuhn HG. 2003. Transient expression of doublecortin during adult neurogenesis. J Comp Neurol 467:1-10.

Brunet JF, Pellerin L, Arsenijevic Y, Magistretti P, Villemure JG. 2002. A novel method for in vitro production of human glial-like cells from neurosurgical resection tissue. Lab Invest 82:809-812.

Brunet JF, Pellerin L, Magistretti P, Villemure JG. 2003. Cryopreservation of human brain tissue allowing timely production of viable adult human brain cells for autologous transplantation. Cryobiology 47:179-183.

Brunet JF, Rouiller E, Wannier T, Villemure JG, Bloch J. 2005. Primate adult brain cell autotransplantation, a new tool for brain repair? Exp Neurol 196:195-198.

Brunet JF, Redmond DEJr, Bloch J. 2009. Primate adult brain cell autotransplantation, a pilot study in asymptomatic MPTP treated monkeys. Cell Transplant 18:787-799.

Burgess HA, Reiner O. 2000. Doublecortin-like kinase is associated with microtubules in neuronal growth cones. Mol Cell Neurosci 16:529-541.

Cai Y, Xiong K, Chu Y, Luo DW, Luo XG, Yuan XY, Struble RG, Clough RW, Spencer DD, Williamson A, Kordower JH, Patrylo PR, Yan XX. 2009. Doublecortin expression in adult cat and primate cerebral cortex relates to immature neurons that develop into GABAergic subgroups. Exp Neurol 216:342-356.

Couillard-Despres S, Winner B, Schaubeck S, Aigner R, Vroemen M, Weidner N, Bogdahn U, Winkler J, Kuhn HG, Aigner L. 2005. Doublecortin expression levels in adult brain reflect neurogenesis. Eur J Neurosci 21:1-14.

des Portes V, Pinard JM, Billuart P, Vinet MC, Koulakoff A, Carrie A, Gelot A, Dupuis E, Motte J, Berwald-Netter Y, Catala M, Kahn A, Beldjord C, Chelly J. 1998. A novel CNS gene required for neuronal migration and involved in X-linked subcortical laminar heterotopia and lissencephaly syndrome. Cell 92:51-61.

Francis F, Koulakoff A, Boucher D, Chafey P, Schaar B, Vinet MC, Friocourt G, McDonnell N, Reiner O, Kahn A, McConnell SK, Berwald-Netter Y, Denoulet P, Chelly J. 1999. Doublecortin is a developmentally regulated, microtubule-associated protein expressed in migrating and differentiating neurons. Neuron 23:247-256. 
Gleeson JG, Allen KM, Fox JW, Lamperti ED, Berkovic S, Scheffer I, Cooper EC, Dobyns WB, Minnerath SR, Ross ME, Walsh CA. 1998. Doublecortin, a brain-specific gene mutated in human X-linked lissencephaly and double cortex syndrome, encodes a putative signaling protein. Cell 92:63-72.

Gleeson JG, Lin PT, Flanagan LA, Walsh CA. 1999. Doublecortin is a microtubule-associated protein and is expressed widely by migrating neurons. Neuron 23:257-271.

Goldman SA, Nedergaard M, Crystal RG, Fraser RA, Goodman R, Harrison-Restelli C, Jiang J, Keyoung HM, Leventhal C, Pincus DW, Shahar A, Wang S. 1997. Neural precursors and neuronal production in the adult mammalian forebrain. Ann N Y Acad Sci 835:30-55.

Gomez-Climent MA, Castillo-Gomez E, Varea E, Guirado R, Blasco-Ibanez JM, Crespo C, Martinez-Guijarro FJ, Nacher J. 2008. A population of prenatally generated cells in the rat paleocortex maintains an immature neuronal phenotype into adulthood. Cereb Cortex 18:2229-2240.

Gould SJ. 1992. Ontogeny and phylogeny-revisited and reunited. Bioessays 14:275-279.

Horesh D, Sapir T, Francis F, Wolf SG, Caspi M, Elbaum M, Chelly J, Reiner O. 1999. Doublecortin, a stabilizer of microtubules. Hum Mol Genet 8:1599-1610.

Jessberger S, Romer B, Babu H, Kempermann G. 2005. Seizures induce proliferation and dispersion of doublecortin-positive hippocampal progenitor cells. Exp Neurol 196: 342-351.

Koizumi H, Higginbotham H, Poon T, Tanaka T, Brinkman BC, Gleeson JG. 2006. Doublecortin maintains bipolar shape and nuclear translocation during migration in the adult forebrain. Nat Neurosci 9:779-786.

Komitova M, Zhu X, Serwanski DR, Nishiyama A. 2009. NG2 cells are distinct from neurogenic cells in the postnatal mouse subventricular zone. J Comp Neurol 512: 702-716.

Levitt P, Barbe MF, Eagleson KL. 1997. Patterning and specification of the cerebral cortex. Annu Rev Neurosci 20:1-24.

Martin R, Gutierrez A, Penafiel A, Marin-Padilla M, de la Calle A. 1999. Persistence of Cajal-Retzius cells in the adult human cerebral cortex. An immunohistochemical study. Histol Histopathol 14:487-490.

Matsuo N, Kawamoto S, Matsubara K, Okubo K. 1998. Cloning and developmental expression of the murine homolog of doublecortin. Biochem Biophys Res Commun 252: 571-576.

Messam CA, Hou J, Major EO. 2000. Coexpression of nestin in neural and glial cells in the developing human CNS defined by a human-specific anti-nestin antibody. Exp Neurol 161:585-596.

Mizuguchi M, Yamanouchi H, Becker LE, Itoh M, Takashima S. 2002. Doublecortin immunoreactivity in giant cells of tuberous sclerosis and focal cortical dysplasia. Acta Neuropathol 104:418-424.

Nacher J, Crespo C, McEwen BS. 2001. Doublecortin expression in the adult rat telencephalon. Eur J Neurosci 14: 629-644.

Omori Y, Suzuki M, Ozaki K, Harada Y, Nakamura Y, Takahashi E, Fujiwara T. 1998. Expression and chromosomal localization of KIAA0369, a putative kinase structurally related to Doublecortin. J Hum Genet 43:169-177.

Palmer TD, Markakis EA, Willhoite AR, Safar F, Gage FH. 1999. Fibroblast growth factor-2 activates a latent neurogenic program in neural stem cells from diverse regions of the adult CNS. J Neurosci 19:8487-8497.

Pecchi E, Dallaporta M, Charrier C, Pio J, Jean A, Moyse E, Troadec JD. 2007. Glial fibrillary acidic protein (GFAP)-positive radial-like cells are present in the vicinity of proliferative progenitors in the nucleus tractus solitarius of adult rat. J Comp Neurol 501:353-368.

Pekcec A, Loscher W, Potschka H. 2006. Neurogenesis in the adult rat piriform cortex. Neuroreport 17:571-574.

Ponti G, Aimar P, Bonfanti L. 2006. Cellular composition and cytoarchitecture of the rabbit subventricular zone and its extensions in the forebrain. J Comp Neurol 498:491-507.

Rao MS, Hattiangady B, Abdel-Rahman A, Stanley DP, Shetty AK. 2005. Newly born cells in the ageing dentate gyrus display normal migration, survival and neuronal fate choice but endure retarded early maturation. Eur J Neurosci 21:464-476.

Shapiro LA, Ng KL, Kinyamu R, Whitaker-Azmitia P, Geisert EE, Blurton-Jones M, Zhou QY, Ribak CE. 2007a. Origin, migration and fate of newly generated neurons in the adult rodent piriform cortex. Brain Struct Funct 212:133-148.

Shapiro LA, Ng KL, Zhou QY, Ribak CE. 2007b. Olfactory enrichment enhances the survival of newly born cortical neurons in adult mice. Neuroreport 18:981-985.

Verwer RW, Sluiter AA, Balesar RA, Baayen JC, Noske DP, Dirven CM, Wouda J, van Dam AM, Lucassen PJ, Swaab DF. 2007. Mature astrocytes in the adult human neocortex express the early neuronal marker doublecortin. Brain 130(Pt 12):3321-3335.

Xiong K, Luo DW, Patrylo PR, Luo XG, Struble RG, Clough RW, Yan XX. 2008. Doublecortin-expressing cells are present in layer II across the adult guinea pig cerebral cortex: partial colocalization with mature interneuron markers. Exp Neurol 211:271-282. 